\title{
Pemetaan Aair Tanah Menggunakan Metode Geolistrik Tahanan Jenis Konfigurasi Dipol-dipol Di Universitas Sam Ratulangi
}

\author{
Mirna Husaina, As'aria*, Seni Helina Juwita Tongkukuta \\ aJurusan Fisika, FMIPA, Unsrat, Manado
}

\begin{tabular}{l} 
K A T A K U N C I \\
\hline Dipol-dipol, RES2DINV, air \\
tanah
\end{tabular}

\begin{abstract}
A B S T R A K
Telah dilakukan penelitian untuk mendeteksi keberadaan air tanah di area Universitas Sam Ratulangi. Penelitian ini menggunakan metode geolistrik resistivitas tahanan jenis konfigurasi Dipol-dipol. Akuisisi data menggunakan Multichannel and Multielectrode resistivity an IP meter 48 simultaneous channel merek MAE X 612-EM. Pengukuran dilakukan pada 11 lintasan dengan panjang masing-masing lintasan 480 meter. Pengolahan data dilakukan dengan menggunakan perangkat lunak Res2Dinv dengan hasil berupa gambar tampang lintang resistivitas model bawah permukaan 2D yang digunakan untuk menentukan posisi akuifer air tanah.

Hasil menunujukkan bahwa adanya lapisan batuan dengan nilai resistivitas rendah yaitu $\rho \leq 280 \Omega$ m. Nilai resistivitas yang merupakan lapisan pembawa air adalah $\rho \leq 25,93 \Omega \mathrm{m}$. Posisi akuifer diperoleh pada lintasan 1, 3, 5, 7, 8 dan 9 .
A B S T R A C T
Research has done to detect the presence of groundwater in the University of Sam Ratulangi area.The research used the dipole-dipole configuration resistivity geoelectic method. Data acquisitions is using Multichannel and Multielectrode resistivity an IP meter 48 simultaneous channel of MAE X 612-EM types. The measurement is done on 11 lines with length of each line is 480 meters. Data processing has been done by using Res2Dinv software and resulted of $2 \mathrm{D}$ resistivity subsurface model which used to determine the groundwater aquifer position.

\begin{tabular}{l} 
K E Y W O R D S \\
\hline $\begin{array}{l}\text { Dipole-dipole, } \\
\text { Groundwater }\end{array}$
\end{tabular}

The results show that the existence of rock layer with low resistivity is $\rho \leq$ $280 \Omega \mathrm{m}$. The resistivity of rock layer of the water aquifer is $\rho \leq 25,93 \Omega \mathrm{m}$. Position of aquifer are obtained in the 1,3,5,7,8, and 9 lines.

\begin{tabular}{l} 
TERSEDIA ONLINE \\
\hline 1 Februari 2017
\end{tabular}

\section{Pendahuluan}

Keberadaan air tanah sangat terbatas baik secara kuantitas maupun kualitas Air tawar merupakan kebutuhan utama bagi manusia. Penduduk di kota-kota besar semakin banyak yang tinggal di daerah sekitar sanitasi tempat pembuangan akhir sampah (sanitary landfill), dan sekitar $80 \%$ memanfaatkan air tanah sebagai sumber air minum.
Jumlah penduduk yang semakin banyak dengan kebutuhan air yang juga semakin banyak, menyebabkan dibutuhkan jumlah air yang cukup, terutama di tempat-tempat umum. Akuifer adalah lapisan bawah tanah yang mengandung air dan dapat mengalirkan air. Keberadaan akuifer air tanah dapat diketahui dengan menggunakan metode dan alat ukur yang dapat mengukur parameterparameter fisika yang berkaitan dengan keberadaan sumber daya air tersebut (Ravindran dan Prabhu, 2012).

*Corresponding author: Jurusan Fisika FMIPA UNSRAT, Jl. Kampus Unsrat, Manado, Indonesia 95115; Email address: mhh230795@gmail.com

Published by FMIPA UNSRAT (2017) 
Salah satu metode eksplorasi geofisika untuk menyelidiki keadaan bawah permukaan dengan menggunakan sifat-sifat kelistrikan batuan. Sifatsifat kelistrikan tersebut antara lain adalah tahanan jenis (Batayneh, 2011). Metode geolistrik telah banyak digunakan untuk menentukan ketebalan dan resistivitas media berlapis untuk tujuan mengetahui potensi air tanah dan penentuan tapak sumur bor di retak akuifer terkekang (Muchingami, dkk 2012).

Resistivitas lapisan batuan di bawah permukaan tanah dalam metode geolistrik dieksplorasi dengan cara mengalirkan arus listrik DC (Direct Current) bertegangan tinggi ke dalam tanah. Injeksi arus listrik ini menggunakan 2 elektroda arus yang ditancapkan ke dalam tanah dengan jarak tertentu. Tegangan listrik yang terdapat di permukaan tanah diukur dengan menggunakan 2 elektroda tegangan (Hewaidy dkk, 2015).

Air yang memiliki sifat konduktor dan berasosiasi dengan batuan yang mempunyai resistivitas berbeda, sehingga semakin banyak kandungan air dalam batuan maka semakin rendah resistivitasnya dan jika kandungan airnya sedikit maka resistivitasnya akan tinggi. Akuifer air tanah mengikuti kontur lapisan tanah yang ada di bawah permukaan. Air yang berada di dalam tanah berasal dari dari resapan air hujan yang jatuh di permukaan, yang kemudian mengalir ke tempat-tempat rendah, kondisi topografi di wilayah Unsrat tidak rata. Di bagian timur tinggi dan bagian barat rendah. Kondisi yang demikian mengakibatkan daerah yang di bagian tengah kesulitan mendapatkan sumber air tanah. Sehingga ketersediaan air tanah di Unsrat dapat dikatakan tidak merata, oleh karenanya perlu dilakukan pemetaan air tanah secara menyeluruh. Eksplorasi dilakukan dengan menggunakan metode resistivitas tahanan jenis konfigurasi dipol-dipol, dan data yang diperoleh dianalisis menggunakan software Res2dinv.

\section{Material dan Metode}

Penelitian dilaksanakan di daerah Kampus Universitas Sam Ratulangi. Penelitian ini dilaksanakan pada bulan Januari sampai Mei 2017. Penelitian dilakukan di laboratorium Geofisika fisika FMIPA.

Alat dan bahan yang digunakan adalah: Satu set alat geolistrik resistivitymeter: Multi-Channel and Multi-Electrode Resistivity and IP Meter MAE X612EM, GPS (Global Postioning System), Laptop, Software RES2DINV, Notepad dan Google Earth.

\section{Hasil dan Pembahasan}

\subsection{Hasil Pengukuran Resistivitas Di Unsrat}

Lintasan Pengukuran resistivitas bawah permukaan di kawasan Unsrat tampak pada Gambar 3.1.

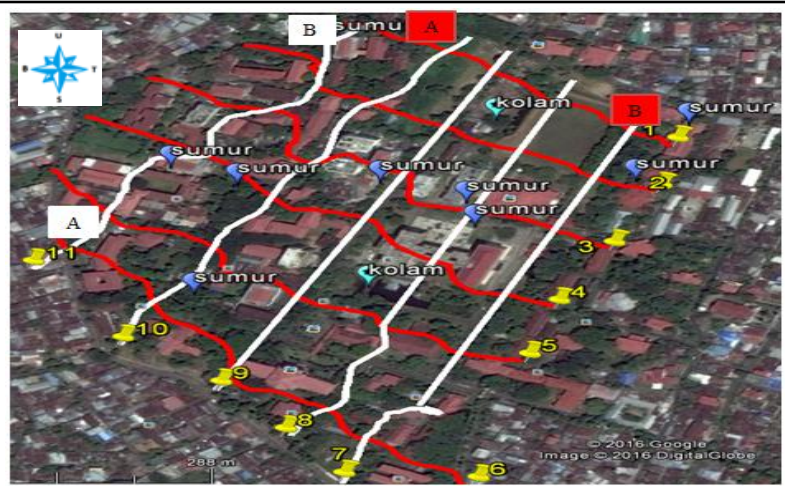

Gambar 3.1 Lintasan Pengukuran resistivitas di Unsrat

Pengukuran dilakukan pada 11 lintasan, dengan panjang tiap lintasan 480 meter. Masingmasing lintasan mempunyai 48 titik elektroda dengan jarak antar titik elektroda 10 meter. Susunan resistivitimeter yang digunakan dalam pengukuran adalah seperti pada Gambar 3.2.

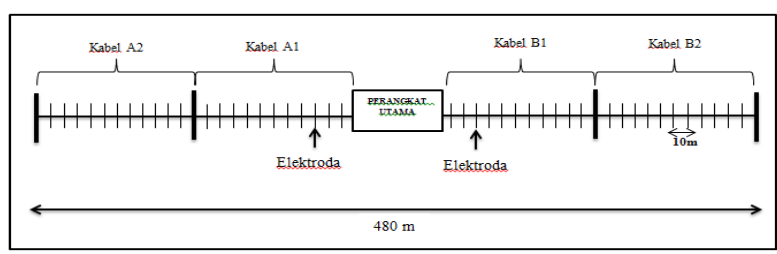

Gambar 3.2. Susunan alat pengukuran resistivitymeter:Multi-Channel and Multi-Electrode Resistivity and IP Meter MAE X612-EM.

Lapisan batuan bawah permukaan dapat diperkirakan dengan melihat nilai resistivitas pada model 2D hasil inversi data pengukuran, warnawarna menunjukkan nilai resistivitas dalam satuan Ohmmeter $(\Omega \mathrm{m})$.

\subsection{Analisis Posisi Akuifer Pada Lokasi Pengukuran}

Akuifer air tanah tidak ditemukan pada setiap lintasan, tetapi hanya pada lintasan 1 , lintasan 3 , lintasan 5, lintasan 7, lintasan 8 dan lintasan 9. Di lapisan tanah yang diduga sebagai lapisan pembawa air mempunyai nilai resistivitas $\leq 25,93$ $\Omega \mathrm{m}$. Posisi akuifer air tanah pada lintasan 1 tampak pada Gambar 3.3, lapiasan tanah yang diduga sebagai akuifer air tanah terdapat pada meter ke 120 sampai meter ke 130 dengan kedalaman 5 sampai 15 meter, pada meter ke 250 sampai meter ke 270 dengan kedalaman 5 sampai 18 meter, dan pada meter ke 320 dengan kedalaman 5 sampai 22 meter. Sumur yang terdapat pada meter ke 480 juga memiliki kedalaman 0.8 meter dari permukaan tanah. 


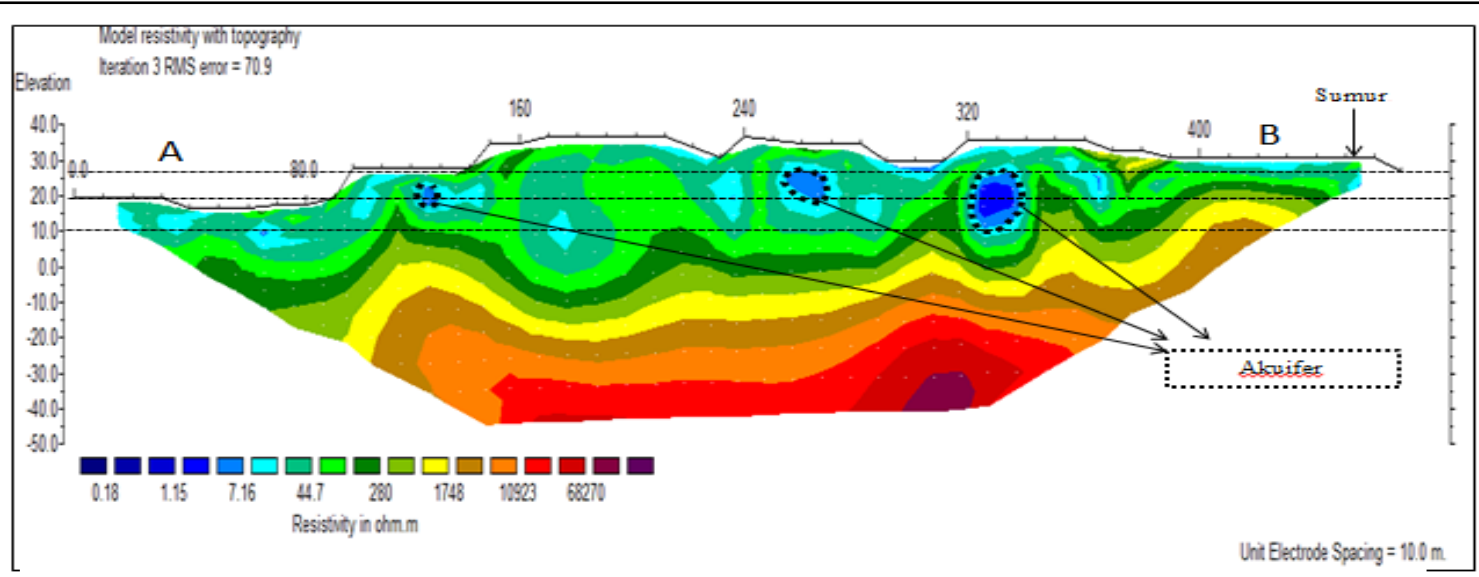

Gambar 3.3 Posisi akuifer pada lintasan 1

Posisi Akuifer air tanah pada lintasan 3 terdapat pada meter ke 270 sampai meter ke 290 dengan kedalaman 0.8 sampai 3 meter, kemudian mulai dari meter ke 300 sampai meter 315 dengan kedalaman 2 sampai 6 meter dan pada meter ke 335 dengan kedalaman 3 sampai 11 meter. Terdapat 2 sumur yang dilewati jalur pengukuran, kedua sumur saling berhadapan dan terletak pada titik elektroda yang ke 27. Kedalaman sumur 0.8 meter dari permukaan tanah, tetapi volume air didalamnya jumlahnya sedikit. Posisi akuifer air tanah lintasan 3 tampak pada Gambar 3.4.
Posisi akuifer air tanah pada lintasan 5 hanya terdapat pada meter ke 50 sampai meter ke 60 dengan kedalaman 1 sampai 5 meter dari permukaan. Posisi akuifer yang diduga sebagai akuifer tersebut tampak pada Gambar 3.5.

Lapisan tanah yang diduga sebagai akuifer air tanah pada lintasan 7, terdapat pada meter ke 245 sampai meter ke 250 dengan kedalaman 5 sampai 12 meter dan pada meter ke 380 sampai meter ke 390 mempunyai kedalaman 1 sampai 9 meter. Posisi akuifer air tanah pada lintasan 7 tampak pada Gambar 3.6

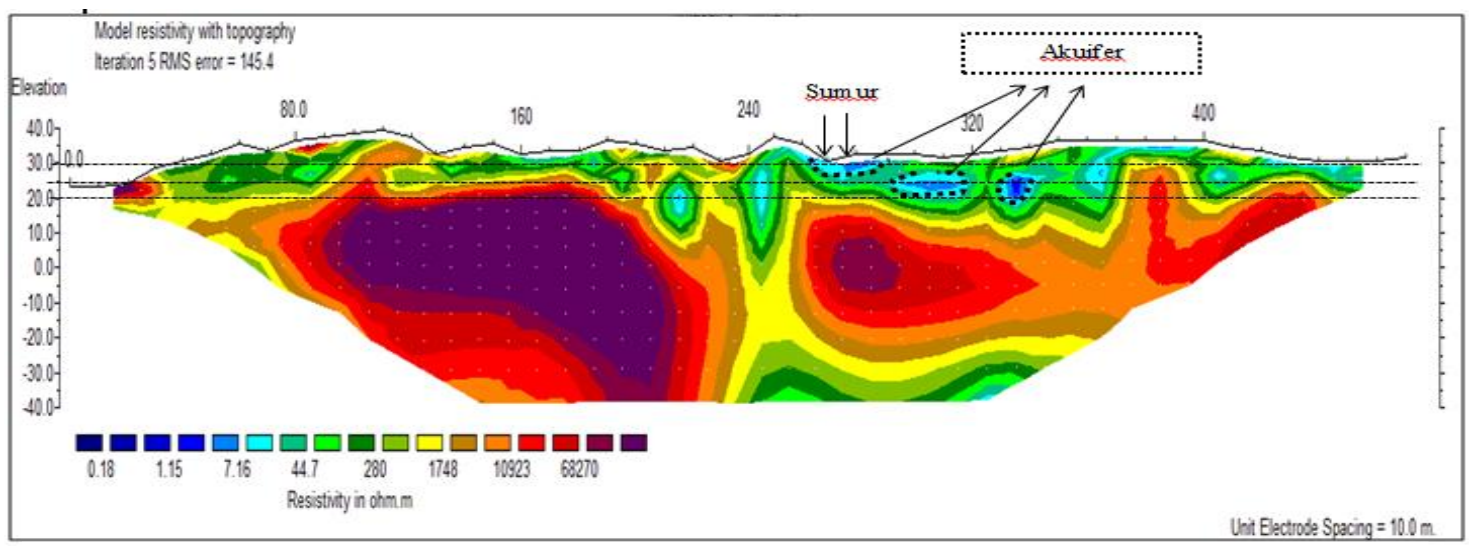

Gambar 3.4 Posisi akuifer pada lintasan 3

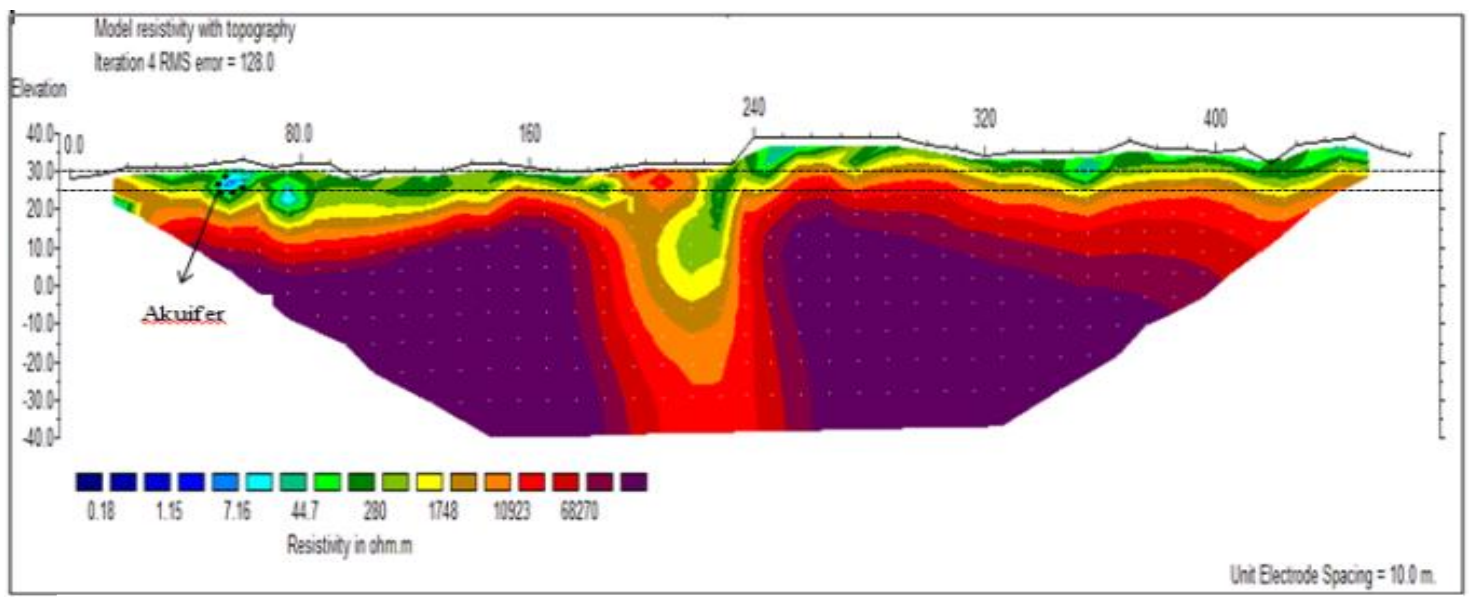

Gambar 3.5 Posisi akuifer pada lintasan 5 


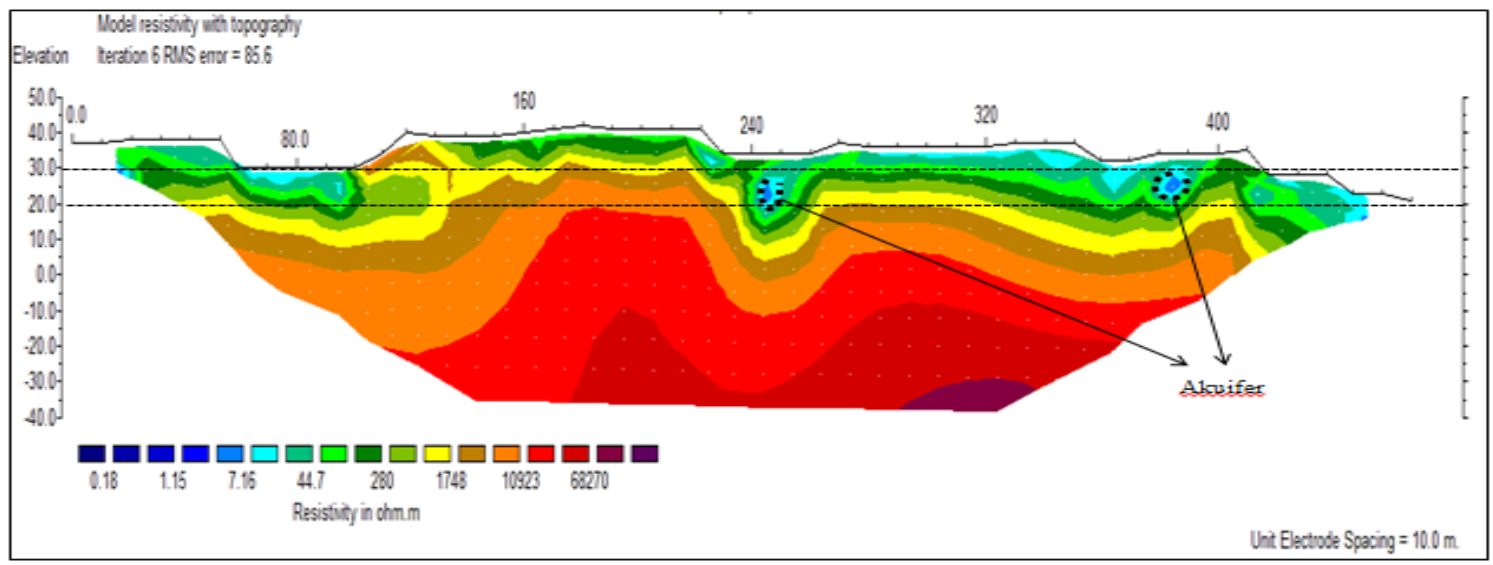

Gambar 3.6 Posisi akuifer pada lintasan 7

Akuifer air tanah pada lintasan 8 mulai dari meter ke 210 sampai meter ke 230 dengan kedalaman 2 sampai 12 meter, kemudian meter ke 235 sampai meter ke 250 dengan kedalaman 5 sampai 35 meter, pada meter ke 280 dengan kedalaman sekitar 0.8 sampai 2 meter dan pada meter ke 370 sampai pada meter ke 400 mempunyai kedalaman 0.8 sampai 5 meter.
Jalur pengukuran melewati 2 kolam dan 2 sumur, sumur yang dilewati jalur pengukuran terdapat pada meter ke 380 dan mempunyai kedalaman 0.8 meter dari permukaan tanah. Posisi akuifer air tanah pada lintasan 8 tampak pada Gambar 3.7.

Berdasarkan Gambar 4.13 lapisan akuifer air tanah terdapat pada meter ke 230 sampai pada meter ke 240 dengan kedalaman 3 sampai 8 meter. Dan pada meter ke 450 dengan kedalaman 7 sampai 14 meter. Posisi akuifer air tanah lintasan 9 tampak pada Gambar 3.8.

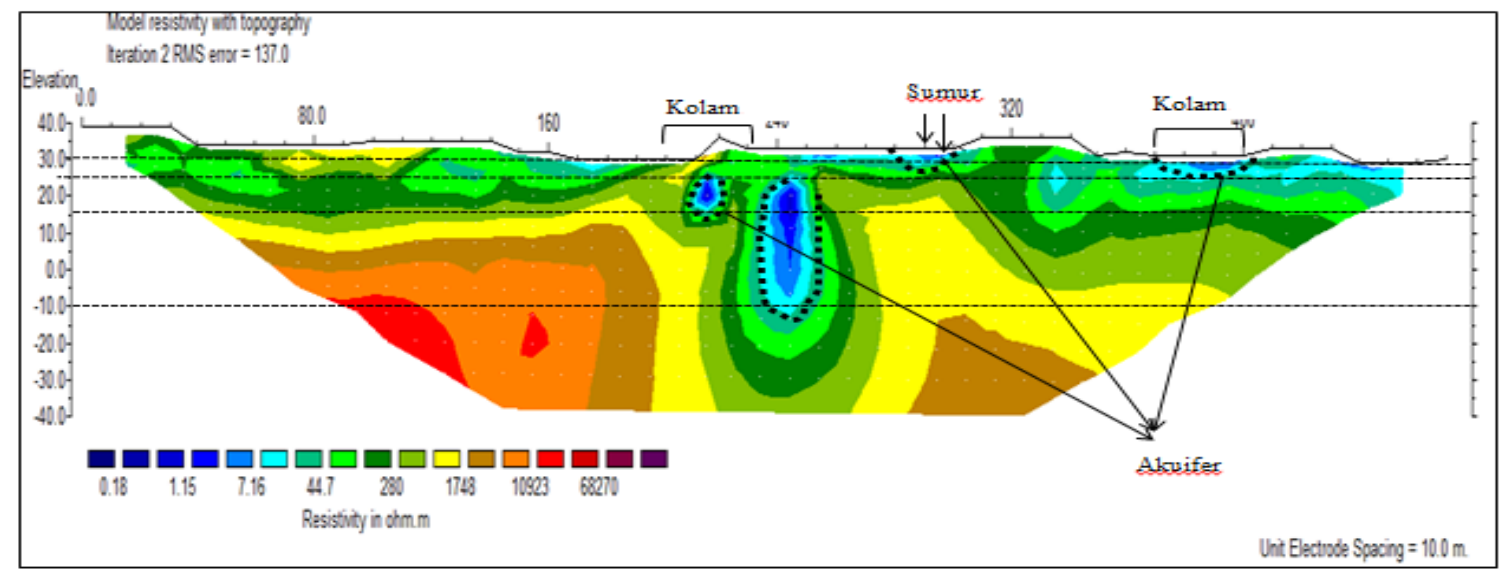

Gambar 3.7 Posisi akuifer pada lintasan 8

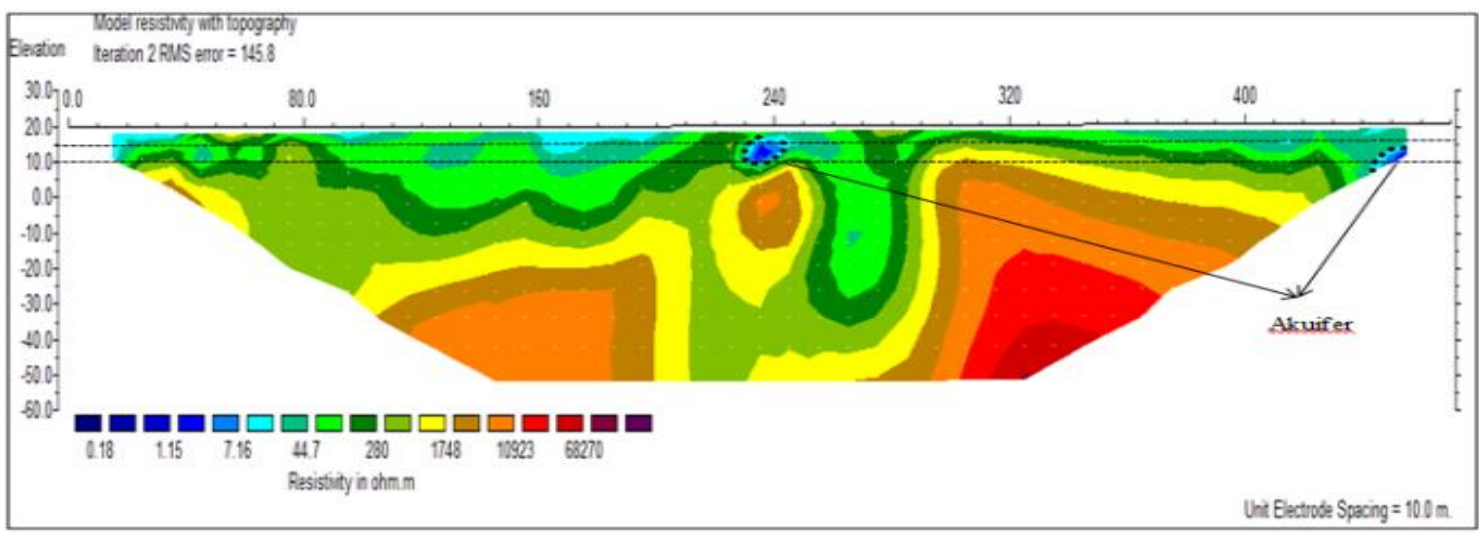

Gambar 3.8 Posisi akuifer pada lintasan 9 
Posisi akuifer air tanah pada lintasan 1, lintasan 3, lintasan 5, lintasan 7, lintasan 8 dan lintasan 9 ditunjukkan dalam peta daerah pengukuran seperti pada Gambar 3.9. Informasi mengenai akuifer, yaitu: lintasan, koordinat dan kedalaman debrikan pada Tabel 3.1.

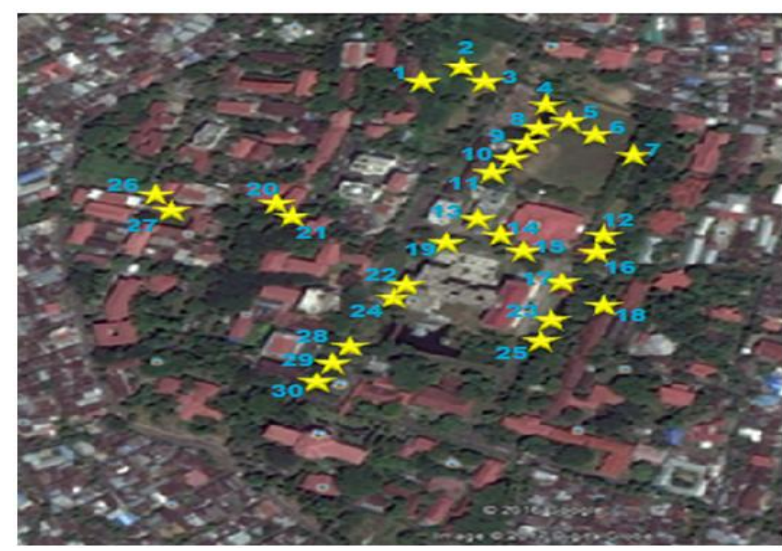

Gambar 3.9 Posisi sebaran akuifer air tanah

Keterangan:

Titik Akuifer

Tabel 3.1 Lintang dan Bujur Pada Titik-titik Akuifer Air Tanah

\begin{tabular}{|c|c|c|c|c|c|}
\hline \multirow{2}{*}{ No } & \multirow{2}{*}{ Akuifer } & \multirow{2}{*}{ Lintasan } & \multicolumn{2}{|c|}{ Koordinat } & \multirow{2}{*}{\begin{tabular}{|c}
$\begin{array}{c}\text { Kedalaman Akuifer } \\
\text { (meter) }\end{array}$ \\
\end{tabular}} \\
\hline & & & Lintang Utara & Bujur Timur & \\
\hline 1 & 1 & 9 & $1^{\circ} 27^{\prime} 649^{\prime \prime}$ & $124^{\circ} 49^{\prime} 606^{\prime \prime}$ & 7 sampai 14 \\
\hline 2 & 2 & 1 & $1^{\circ} 27^{\prime} 652^{\prime \prime}$ & $124^{\circ} 49^{\prime} 669^{\prime \prime}$ & \multirow{2}{*}{5 sampai 15} \\
\hline 3 & 3 & 1 & $1^{\circ} 27^{\prime} 655^{\prime \prime}$ & $124^{\circ} 49^{\circ} 662^{\prime \prime}$ & \\
\hline 4 & 4 & 1 & $1^{\circ} 27^{\circ} 611^{\prime \prime}$ & $124^{\circ} 49^{\circ} 713^{\prime \prime}$ & \multirow{3}{*}{5 sampai 18} \\
\hline 5 & 5 & 1 & $1^{\circ} 27^{\prime} 606^{\prime \prime}$ & $124^{\circ} 49^{\circ} 721^{\prime \prime}$ & \\
\hline 6 & 6 & 1 & $1^{\circ} 27^{\prime} 605^{\prime \prime}$ & $124^{\circ} 49^{\prime} 727^{\prime \prime}$ & \\
\hline 7 & 7 & 1 & $1^{\circ} 27^{\prime} 597^{\prime \prime}$ & $124^{\circ} 49^{\prime} 740^{\prime \prime \prime}$ & 5 sampai 22 \\
\hline 8 & 8 & 8 & $1^{\circ} 27^{\prime} 487^{\prime \prime}$ & $124^{\circ} 49^{\circ} 712^{\prime \prime}$ & \multirow{4}{*}{0.8 sampai 5} \\
\hline 9 & 9 & 8 & $1^{\circ} 27^{\prime} 487^{\prime \prime}$ & $124^{\circ} 49^{\prime} 712^{\prime \prime}$ & \\
\hline 10 & 10 & 8 & $1^{\circ} 27^{\prime} 487^{\prime \prime}$ & $124^{\circ} 49^{\circ} 712^{\prime \prime}$ & \\
\hline 11 & 11 & 8 & $1^{\circ} 27^{\prime} 487^{\prime \prime}$ & $124^{\circ} 49^{\circ} 712^{\prime \prime}$ & \\
\hline 12 & 12 & 7 & $1^{\circ} 27^{\prime} 448^{\prime \prime}$ & $124^{\circ} 49^{\circ} 762^{\prime \prime \prime}$ & 1 sampai 9 \\
\hline 13 & 13 & 3 & $1^{\circ} 27^{\prime} 498^{\prime \prime}$ & $124^{\circ} 49^{\circ} 697^{\prime \prime}$ & \multirow{3}{*}{0.8 sampai 3} \\
\hline 14 & 14 & 3 & $1^{\circ} 27^{\prime} 496^{\prime \prime}$ & $124^{\circ} 49^{\circ} 700^{\prime \prime}$ & \\
\hline 15 & 15 & 3 & $1^{\circ} 27^{\prime} 493^{\prime \prime}$ & $124^{\circ} 49^{\circ} 706^{\prime \prime}$ & \\
\hline 16 & 16 & 7 & $1^{\circ} 27^{\prime} 439^{\prime \prime}$ & $124^{\circ} 49^{\prime} 755^{\prime \prime}$ & 1 sampai 9 \\
\hline 17 & 17 & 3 & $1^{\circ} 27^{\prime 4} 493^{\prime \prime \prime}$ & $124^{\circ} 49^{\circ} 706^{\prime \prime}$ & 2 sampai 6 \\
\hline 18 & 18 & 3 & $1^{\circ} 27^{\prime} 486^{\prime \prime}$ & $124^{\circ} 49^{\prime} 720^{\prime \prime}$ & 3 sampai 11 \\
\hline 19 & 19 & 8 & $1^{\circ} 27^{\circ} 436^{\prime \prime}$ & $124^{\circ} 49^{\circ} 706^{\prime \prime}$ & 0.8 sampai 2 \\
\hline 20 & 20 & 9 & $1^{\circ} 27^{\prime} 563^{\prime \prime}$ & $124^{\circ} 49^{\prime} 534^{\prime \prime}$ & \multirow{2}{*}{3 sampai 8} \\
\hline 21 & 21 & 9 & $1^{\circ} 27^{\prime} 564^{\prime \prime}$ & $124^{\circ} 49^{\circ} 540^{\prime \prime \prime}$ & \\
\hline 22 & 22 & 8 & $1^{\circ} 27^{\prime} 436^{\prime \prime}$ & $124^{\circ} 49^{\prime} 684^{\prime \prime}$ & 5 sampai 30 \\
\hline 23 & 23 & 7 & $1^{\circ} 27^{\prime} 381^{\prime \prime}$ & $124^{\circ} 49^{\prime} 731^{\prime \prime}$ & 5 sampai 12 \\
\hline 24 & 24 & 8 & $1^{\circ} 27^{\prime} 436^{\prime \prime \prime}$ & $124^{\circ} 49^{\circ} 684^{\prime \prime}$ & 5 sampai 30 \\
\hline 25 & 25 & 7 & $1^{\circ} 27^{\prime} 373^{\prime \prime}$ & $124^{\circ} 49^{\circ} 729^{\prime \prime}$ & 5 sampai 12 \\
\hline 26 & 26 & 5 & $1^{\circ} 27^{\prime} 403^{\prime \prime}$ & $124^{\circ} 49^{\circ} 576^{\prime \prime}$ & \multirow{2}{*}{1 sampai 5} \\
\hline 27 & 27 & 5 & $1^{\circ} 27^{\prime} 399^{\prime \prime}$ & $124^{\circ} 49^{\circ} 580^{\prime \prime}$ & \\
\hline 28 & 28 & 8 & $1^{\circ} 27^{\prime} 405^{\prime \prime}$ & $124^{\circ} 49^{\circ} 665^{\prime \prime}$ & \multirow{3}{*}{2 sampai 12} \\
\hline 29 & 29 & 8 & $1^{\circ} 27^{\prime} 405^{\prime \prime}$ & $124^{\circ} 49^{\circ} 765^{\prime \prime}$ & \\
\hline 30 & 30 & 8 & $1^{\circ} 27^{\prime} 431^{\prime \prime}$ & $124^{\circ} 49^{\circ} 679^{\prime \prime}$ & \\
\hline
\end{tabular}

\section{Kesimpulan}

Hasil penelitian pemetaan akuifer air tanah menggunakan metode tahanan jenis konfigurasi Dipol-dipol di Universitas Sam Ratulangi. Dapat disimpulkan bahwa di area Universitas Sam Ratulangi ditemukan beberapa akuifer yang potensial dijadikan sebagai sumber air tanah. Lokasi akuifer yang potensial terdapat pada: Lintasan 1, terdapat pada meter ke 120 sampai meter ke 130 dengan kedalaman 5 sampai 15 meter, pada meter ke 250 sampai meter ke 270 dengan kedalaman 5 sampai 18 meter, dan pada meter ke 320 dengan kedalaman 5 sampai 22 meter. Lintasan 3 terdapat pada meter ke 270 sampai meter ke 290 dengan kedalaman 0.8 sampai 3 meter, kemudian mulai dari meter ke 300 sampai meter 315 dengan kedalaman 2 sampai 6 meter dan pada meter ke 335 dengan kedalaman 3 sampai 11 meter. Lintasan 8, terdapat dari meter ke 210 sampai meter ke 230 dengan kedalaman 2 sampai 12 meter, kemudian meter ke 235 sampai meter ke 250 dengan kedalaman 5 sampai 35 meter, pada meter ke 280 dengan kedalaman sekitar 0.8 sampai 2 meter dan pada meter ke 370 sampai pada meter ke 400 mempunyai kedalaman 0.8 sampai 5 meter.

\section{Daftar Pustaka}

Batayneh, Awni, T. 2011. Aplication of geoelectric methods on paleoenplanteau. Journal of King Saud University-Science. 23: 381-388.

Hewaidy, Abdel Galil A et al, 2015. Groundwater exploration using resistivity and magnetic data at the northwestern part of the Gulf of Suez, Egypt. Egyptian Journal of Petroleum. 24:255263

Muchingami, Innocent et al. 2012. Electrical resistivity survey for groundwater investigations and shallow subsurface evaluations of the basaltc-greenstone formation of the urban Balawayo aquifer. Physics and chemistry of the Earth. 50-52: 44-51.

Ravindran, Antony, and Prabhu $\mathrm{H}$, Mohd.Abdul kadar 2012. Groundwater exploration study using Wenner-Schlumberger electrical array through W-4 2DResistivity Imaging System at Mahallipuram, Chennai, Tamilanadu, India. Research Joornal of Resent Sciences. 1(11): 36-40.

Saranga, Herbhi Tumba, As'ari, Seni H.J Tongkukut. 2016. Deteksi air tanah menggunakan metode geolistrik resistivitas konfigurasi WennerSchlumberger di Masjid Kampus Universitas Sam Ratulangi dan sekitarnya. Jurnal Mipa Unsrat Online 5(2): 70-75. 